\title{
Biosynthesis, characterization and antimicrobial studies of green synthesized silver nanoparticles from fruit extract of Syzygium alternifolium (Wt.) Walp. an endemic, endangered medicinal tree taxon
}

\author{
P. Yugandhar ${ }^{1} \cdot$ N. Savithramma ${ }^{1}$
}

Received: 1 January 2015/Accepted: 6 March 2015/Published online: 19 March 2015

(c) The Author(s) 2015. This article is published with open access at Springerlink.com

\begin{abstract}
In nanotechnology, the plant mediated synthesis of nanoparticles has terrific application in biomedicine due to its novel properties and its eco-friendly nature. The present study deals with the biosynthesis of stable silver nanoparticles (SNPs) from aqueous fruit extract of $S$. alternifolium an endemic medicinal plant to Eastern Ghats. The synthesized nanoparticles are characterized by UVVIS spectroscopy, FTIR, XRD, AFM, SEM with EDAX and TEM. Colour change from brown to grey indicates the formation of nanoparticles and UV-VIS surface plasmon resonance spectroscopy observed at $442 \mathrm{~nm}$ further confirms the synthesized nanoparticles are SNPs. FTIR studies reveal that the phenols and primary amines of proteins are main responsible for reduction, stabilization and capping agents towards these SNPs. The XRD data show crystalline nature of nanoparticles and EDAX measurements reveal the $(12.74 \%)$ percentage presence of Ag metal. AFM, SEM and TEM microscopic analyses revealed that the size of synthesized SNPs ranging from 5 to $68 \mathrm{~nm}$ has spherical shape and they are in polydispersed condition. Further, the antimicrobial studies of synthesized SNPs show high toxicity towards different bacterial and fungal isolates. This is the first report on fruit mediated synthesis of silver nanoparticles from S. alternifolium.
\end{abstract}

Keywords Syzygium alternifolium - Endemic medicinal plant - Characterization of SNPs - Antimicrobial activity

P. Yugandhar

yugandharbotany@gmail.com

1 Department of Botany, Sri Venkateswara University, Tirupati 517502, Andhra Pradesh, India

\section{Introduction}

In the recent past, nanoparticles are gaining much importance in the fields of biology, medicine, and electronics owing to their unique physical and biological properties (Morones et al. 2005). Biosynthesis of nanoparticles using plant materials is easy, efficient, and eco friendly in comparison to chemical mediated or microbe mediated synthesis (Anamika et al. 2012). Recently different types of nanoparticles are synthesized using plant materials like Indium oxide nanoparticles from Aloe vera (Maensiria et al. 2008), Iron oxide nanoparticles from Medicago sativa (Herrera-Becerra et al. 2008), Palladium nanoparticles from Cinnamomum camphora (Yang et al. 2009), Copper nanoparticles from Magnolia kobus (Lee et al. 2013), Cadmium Oxide Nanoparticles from Achillea wilhelmsii (Javad and Sasan 2013). Calcium nanoparticles from Boswellia ovalifoliolata (Yugandhar and Savithramma 2013), Zinc oxide nanoparticles from Catharanthus roseus (Bhumi and Savithramma 2014a), Silver nanoparticles from Abrus precatorius (Bhumi and Savithramma 2014b), and Gold nanoparticles from Avena sativa (Veronica et al. 2004).

Silver has long been known to have strong inhibitory and bactericidal effects as well as a broad spectrum of antimicrobial activities even at low concentrations (Morones et al. 2005). Hence, among the metal nanoparticles, SNPs synthesized from medicinal plants have received much attention in various biological activities like antibacterial (Savithramma et al. 2011a), antifungal (Savithramma et al. 2011b), anthelmintic (Seema and Amrish 2012), antilarvicidic (Sundaravadivelan et al. 2013), antioxidant (Swamy et al. 2014), anticancer (Vasanth et al. 2014), antiinflammatory (Rafie and Hamed 2014), hepatoprotective (Bhuvaneswari et al. 2014) and wound healing (Seema et al. 2014) activities. 
S. alternifolium belongs to the family Myrtaceae and is locally known in Telugu language as mogi or adavineredu. It occurs in the upper plateau, slopes and valley tops with dry, slaty and rocky conditions at an elevation ranging from 600 to $1000 \mathrm{~m}$ in Sri Venkateswara Wildlife Sanctuary of Chittoor and Cuddapah District of Eastern Ghats (Mohan and Lakshmi 2000). Reddy and Reddy (2008) and Andhra Pradesh State Biodiversity Board (Biodiversity news 2009) documented that $S$. alternifolium is an endemic and globally endangered species as per the criteria of IUCN-CAMP to this area. The ripen fruits are used to make squashes and jellies (The Wealth of India 1976). Chenchu and Nakkala tribes of Japali hanuman theertham make the fruits into fine powder and are used for the treatment of diabetes (Savithramma et al. 2014a). Fruit powder is used to treat Diarrhoea by Yanadi tribe and local villagers of Veyilingalakona sacred grove (Savithramma et al. 2014b). Antidiabetic properties were scientifically proved in normal and Alloxan-induced diabetic rats (Rao and Rao 2001). The fruit juice is used to cure stomach ache and its ulcers, external application of fruit pulp reduces rheumatic pains (Rao 2004). Antiulcer properties were experimentally studied in Ethanol and Indomethacin induced gastric ulcers in albino rats show significant decrease of ulcers, proven as effective antiulcer agent (Zeba et al. 2012). In recent studies synthesis of SNPs from endemic medicinal plants like Pterocarpus santalinus (Gopinath et al. 2013), Boswellia ovalifoliolata (Ankanna et al. 2010) and Shorea tumbuggaia (Venkateswarlu et al. 2010) having very rich source of phenols and proteins (Savithramma et al. 2010; Ankanna and Savithramma 2011) act as a good source towards the reduction of nanoparticles. There is no report on synthesis of SNPs from S. alternifolium so far. Hence the present study was undertaken to synthesize the stable silver nanoparticles and validate its antimicrobial activity.

\section{Materials and methods}

\section{Plant collection and extract preparation}

The ripen fruits were collected from Nagatheertham area of Tirumala hills, Chittoor District of Andhra Pradesh, India and are identified by the Flora of the Presidency of Madras (Gamble 1915-1936) and cross checked by herbarium (voucher no. 121) deposited in Department of Botany, Sri Venkateswara University, Tirupati. The fruits were washed several times with tap water to remove the dust particles and shade dried to evaporate the residual moisture. $25 \mathrm{~g}$ of powdered fruits were extracted with $100 \mathrm{ml}$ of milli q water on boiling water bath for $30 \mathrm{~min}$. The aqueous extract was separated by filtration with Whatman No. 1 filter paper and stored at room temperature for biosynthesis of SNPs.

\section{Synthesis of SNPs}

$5 \mathrm{ml}$ of aqueous fruit extract were taken into clean $250 \mathrm{ml}$ conical flask and titrate with $50 \mathrm{ml}$ of $1 \mathrm{mM} \mathrm{Ag}\left(\mathrm{NO}_{3}\right)_{2}$ solution at the temperature range between 60 and $80{ }^{\circ} \mathrm{C}$. Colour change from brown to grey indicates the formation of SNPs. The contents were centrifuged at 10,000 rpm for 20 min to remove the presence of biological admixtures and were used for characterization and antimicrobial activity.

\section{Characterization of SNPs}

UV-VIS absorption spectra of SNPs were measured using a Spectro UV 2080 Double beam 1200 L/mm spectrophotometer. Fourier transform infra red (FT-IR) spectra for extract of fruit powder and silver nanoparticles were analyzed in the range of $4000-500 \mathrm{~cm}^{-1}$ with an ALPHA interferometer (ECO-ATR), Bruker, Ettlingen, Karlsruhe, Germany by $\mathrm{KBr}$ pellet method. Crystalline metallic silver nanoparticles were examined using an X-Ray Diffractometer (Shimadzu, XRD-6000) equipped with $\mathrm{Cu} \mathrm{K} \alpha$ radiation source using $\mathrm{Ni}$ as filter at a setting of $30 \mathrm{kV} /$ $30 \mathrm{~mA}$. Atomic force microscopy (AFM) analysis for synthesized SNPs was done by using the instrument NOVA NT-MDT SOLVER NEXT, RUSSIA. Scanning electron microscopy (SEM) and percentage of silver ions of synthesized SNPs were done using a FEI Quanta 200 FEG HR-SEM machine equipped with EDAX instrument. TEM analysis is performed by using HF-3300 advanced $300 \mathrm{kV}$ TEM/STEM from Hitachi.

\section{Antimicrobial studies of SNPs}

Biosynthesized silver nanoparticles were analyzed for antimicrobial activity against two Gram-positive bacterial strains like Bacillus subtilis ATCC 6633, Staphylococcus aureus ATCC 6538 and five Gram-negative bacterial strains like Escherichia coli ATCC 25922, Klebsiella pneumoniae ATCC 43816, Proteus vulgaris ATCC 13315, Pseudomonas aeruginosa ATCC 15442 and Salmonella typhimurium ATCC 14028. Antifungal studies were carried out in five fungal strains like Alternaria solani ATCC 32904, Aspergillus niger ATCC 16404, Aspergillus flavus ATCC 9643, Penicillium chrysogenum ATCC 11709 and Trichoderma harzianum ATCC 20476 procured from Department of Microbiology, Sri Venkateswara University, Tirupati. Disc diffusion assay method was carried out using standard protocol (Cruickshank 1986). $20 \mu \mathrm{l}$ of Plnat extract, $\mathrm{Ag}\left(\mathrm{NO}_{3}\right)_{2}$, SNPs and Streptomycin/Fluconazole was applied on separate filter paper discs (Whatman No. 1 filter paper with $6 \mathrm{~mm}$ diameter), and allowed to dry before being placed on the agar medium. Triplicates of each 
extract was tested and incubated at $37{ }^{\circ} \mathrm{C}$ for $24 \mathrm{~h}$ in inoculation chamber. Diameter of the zones was measured with the help of scale and the results were tabulated.

\section{Results and discussion}

The first and the foremost conformation of synthesized nanoparticles on visual basis by colour change from brown to grey indicate the synthesized nanoparticles are SNPs (Fig. 1). The colour difference was due to reduction of silver ions (Sankar et al. 2014). Still to date there is no proper mechanism explains towards the reduction of SNPs. Some hypothesis explains $\mathrm{NAD}^{+}$and Ascorbic acid found in all higher plants. $\mathrm{NAD}^{+}$is a coenzyme involved in redox reactions, carrying electron from one reaction to another. $\mathrm{NAD}^{+}$accepts electrons from other molecules and becomes reduced to NADH, which donates electrons. Ascorbic acid is a reducing agent and can reduce and neutralize reactive oxygen species to form ascorbate radical and electron. In these both reactions electrons are formed, which are responsible for the reduction of $\mathrm{Ag}$ ions to $\mathrm{Ag}$ nanoparticles $\left(\mathrm{Ag}^{0}\right.$ state). This is the principle mechanism involved in reduction and colour change pattern of SNPs.

\section{UV-VIS analysis}

The reduction of pure silver ions were monitored by measuring UV-Vis spectrum of reaction medium from the wavelength of 190 to $750 \mathrm{~nm}$. The peak obtained at $442 \mathrm{~nm}$ indicates the presence of silver nanoparticles (Fig. 2). The same type of results were obtained in the case

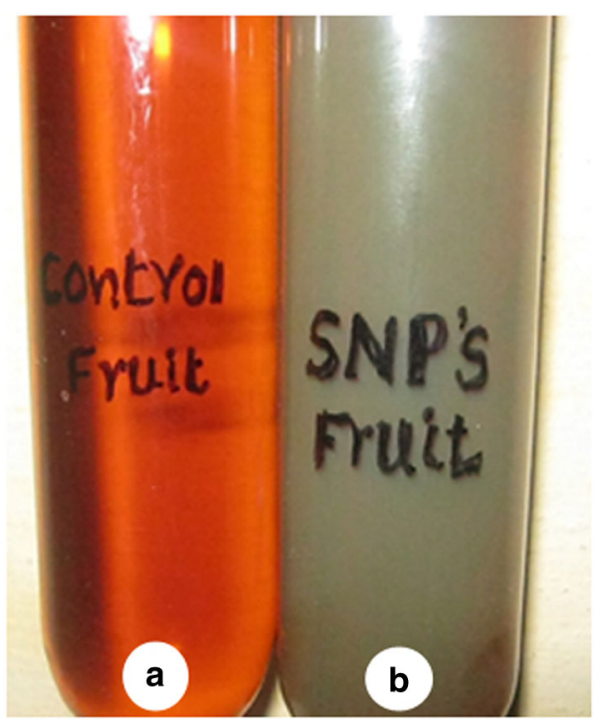

Fig. 1 Colour change pattern, a fruit extract, b synthesized SNPs

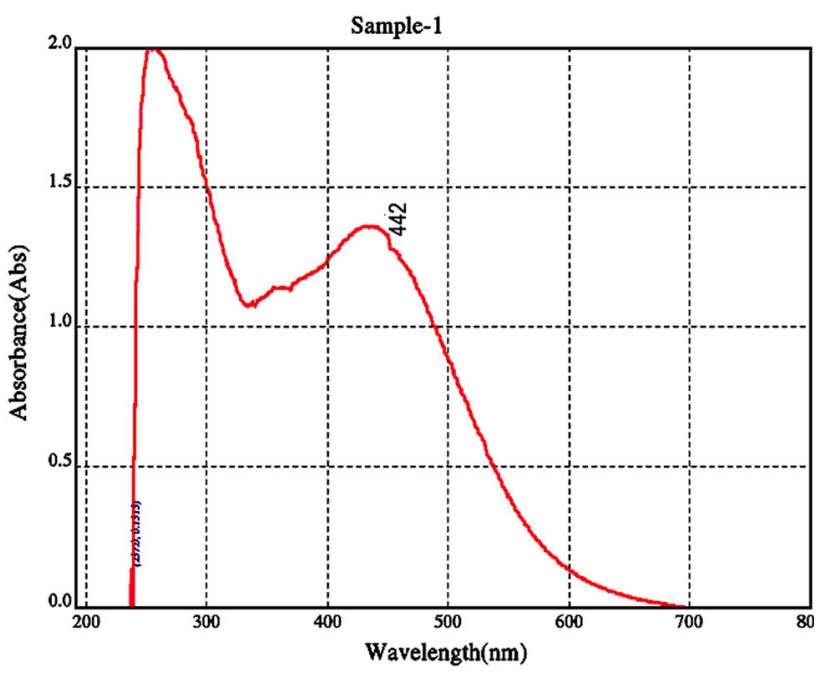

Fig. 2 Surface Plasmon Resonance analysis from UV-VIS spectroscopy shows broad peak at $442 \mathrm{~nm}$

of seed mediated synthesis of silver nanoparticles from Cuminum cyminum (Sankar and Dipak 2014). Nanoparticles absorb light at different wavelengths of UV-VIS and excited due to charge density at the interface between conductor and insulator, the mechanism known as surface plasmon resonance.

\section{FT-IR analysis}

The functional groups of fruit extract and synthesized SNPS were identified using FT-IR spectroscopy between the scan range of $4000-500 \mathrm{~cm}^{-1}$. The FT-IR spectrum obtained for fruit extract (Fig. 3a) displays a number of absorption peaks like $3936 \mathrm{~cm}^{-1}$ assigned for water molecules, $3251 \mathrm{~cm}^{-1}$ for $\mathrm{O}-\mathrm{H}$ bond of alcohols/phenols, $2921 \mathrm{~cm}^{-1}$ for $\mathrm{N}-\mathrm{H}$ bond of ammonium ions, $2306 \mathrm{~cm}^{-1}$ for $\mathrm{C}=\mathrm{O}$ bond of carboxylic acids, $1607 \mathrm{~cm}^{-1}$ for $\mathrm{N}-\mathrm{H}$ bond of ammonium ions, $1350 \mathrm{~cm}^{-1}$ for $\mathrm{N}-\mathrm{O}$ bond of nitro compounds, $1232 \mathrm{~cm}^{-1}$ for $\mathrm{C}-\mathrm{O}$ bond of ethers, $1004 \mathrm{~cm}^{-1}$ for $\mathrm{C}-\mathrm{N}$ bond of amines, $760 \mathrm{~cm}^{-1}$ for $\mathrm{C}-\mathrm{H}$ bond of aromatic benzene and $688 \mathrm{~cm}^{-1}$ for $\mathrm{O}-\mathrm{H}$ bond of alcohols/phenols. Whereas in the case of FTIR spectra of synthesized SNPs (Fig. 3b) showed $3325 \mathrm{~cm}^{-1}$ assigned for $\mathrm{O}-\mathrm{H}$ bond of alcohols/phenols and $1636 \mathrm{~cm}^{-1}$ for $\mathrm{O}-\mathrm{H}$ bond of primary amines. Most of the peaks appeared in the fruit extract disappeared after synthesis of SNPs. Based on FT-IR analysis it is confirmed that the broad peaks of phenols $\left(3325 \mathrm{~cm}^{-1}\right)$ and primary amines of proteins $\left(1636 \mathrm{~cm}^{-1}\right)$ are interacting with biosynthesized SNPs and acting as a reducing agents (Fig. 3b). Same type of results was found in Myristica fragrans seed extract mediated synthesis of silver nanoparticles (Sharma et al. 2014). These FTIR studies suggest that hydroxyl groups of phenols and amide groups of proteins form a layer to the 
Fig. 3 a FTIR spectrum of fruit extract, b FTIR spectrum of synthesized SNPs a

SRI VENKATESWARA UNIVERSITY, TIRUPATI, AP

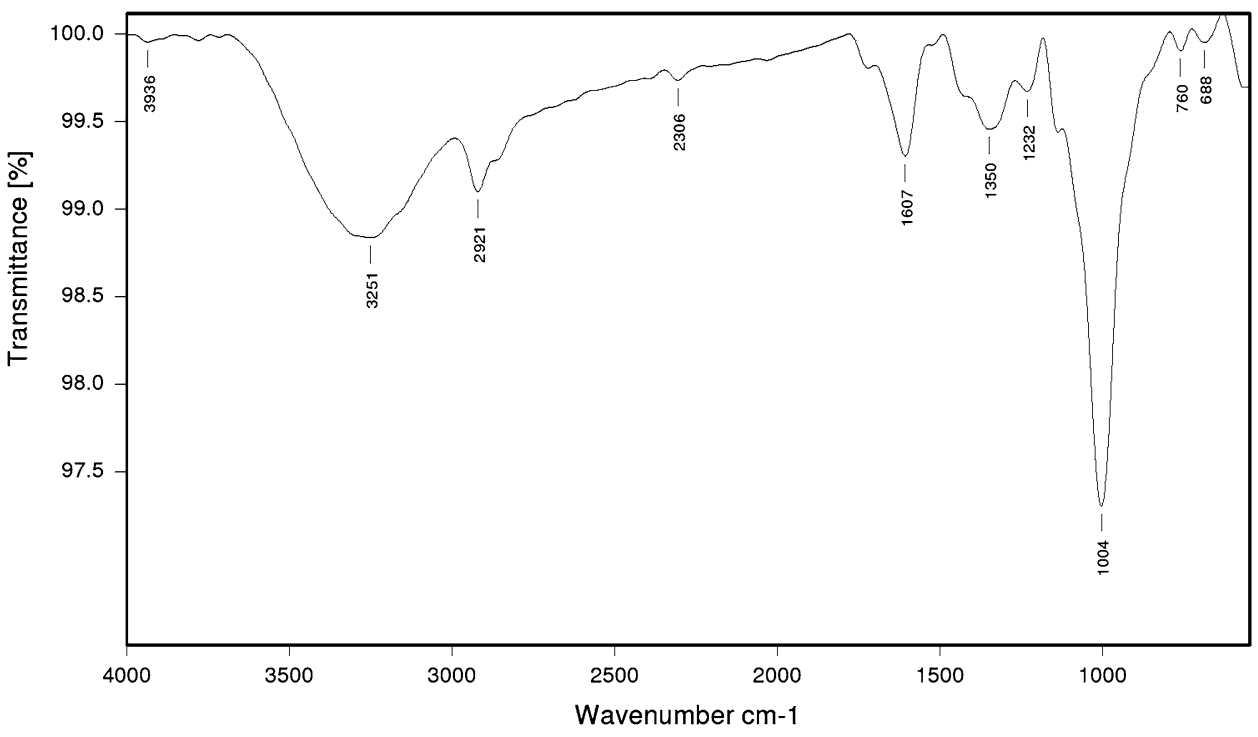

b

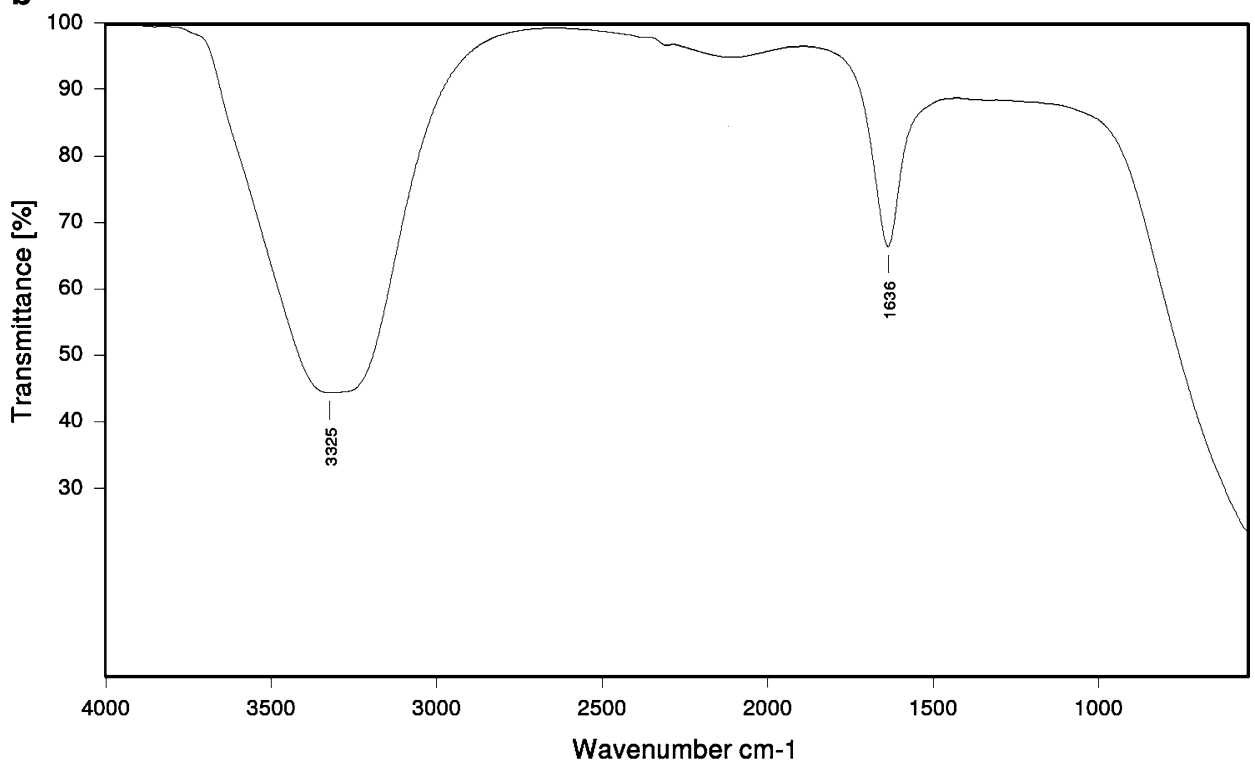

nanoparticles and act as a capping agent to prevent agglomeration and provide stability to the medium (Sathyavathi et al. 2010).

\section{XRD analysis}

X-ray diffraction analysis was carried out to confirm the nature of the nanoparticles. The peaks at $2 \theta$ values of $X$ axis shows $38.09^{\circ}, 44.25^{\circ}, 64.36^{\circ}$ and $77.55^{\circ}$ corresponding to $556.45,152.21,111.73$ and 157.41 Bragg reflections of $Y$-axis, respectively, which may be indexed based on the face-centered cubic structure of silver. X-ray diffraction results clearly shows that the silver nanoparticles formed

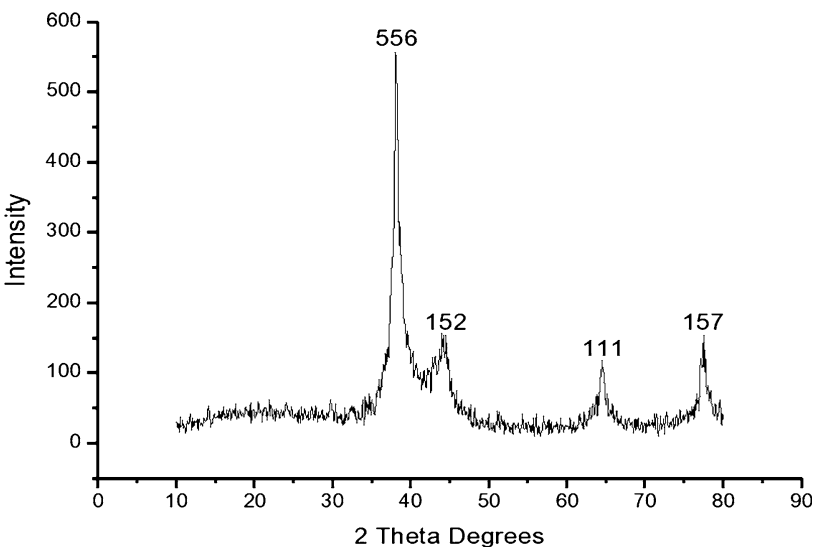

Fig. 4 XRD analysis of synthesized SNPs shows Bragg reflections 
by the reduction of $\mathrm{Ag}+$ ions by the fruit extract are crystalline in nature. The full width at half maximum (FWHM) values i.e., $k=0.44$ were derived from $38.09^{\circ}$, $44.25^{\circ}, 64.36^{\circ}$ and $77.55^{\circ}$ bragg reflections of $\mathrm{X}$-axis. This ' $k$ ' value is substituted in Debye Sherrer's equation $[D=k \lambda / \beta(\cos \theta)]$ getting $44 \mathrm{~nm}$ size of synthesized nanoparticles (Fig. 4).

\section{AFM analysis}

Surface topology of the synthesized SNPs was studied by $2 \times 2 \mu \mathrm{m}$ atomic force microscopy (AFM) analysis
(Fig. 5a). AFM was used as the primary method to monitor SNPs dissolution and agglomeration pattern. The topography of AFM micrographs clearly indicate that the formulated SNPs possess spherical shape, size range between 32 and $68 \mathrm{~nm}$, without any agglomerations. A statistical treatment of AFM images was performed using specially designed image processing software (NOVA-TX) to further exploit these images and explore the 3D nanostructures (Fig. 5b). In Fig. 5c and d, the average size of the nanoparticles from particular magnified area is analyzed by NOVA-TX software i.e., $34 \mathrm{~nm}$. Here the $X$-axis shows size of the particles and $Y$-axis showing number of particles.

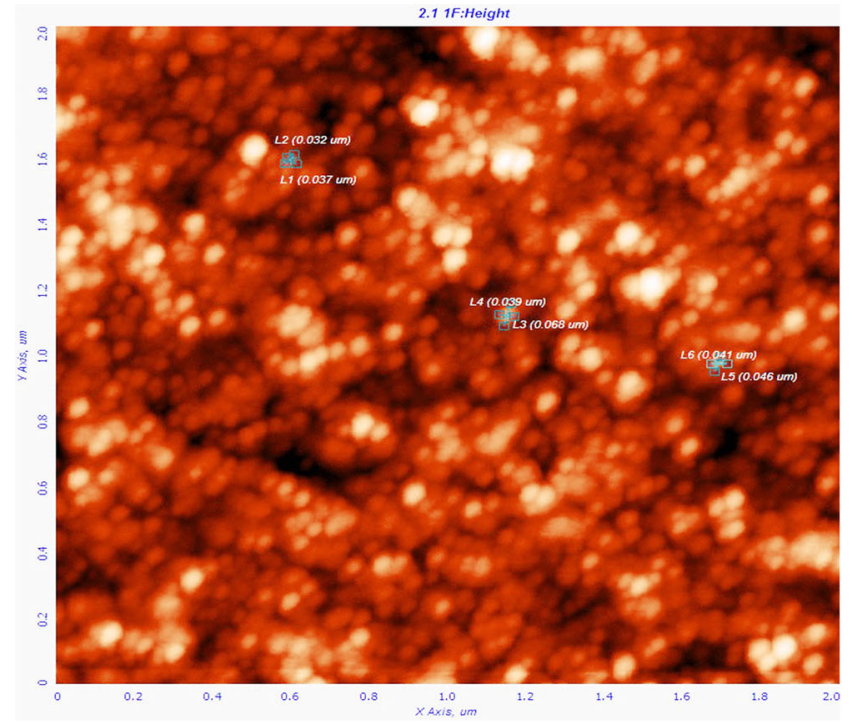

a

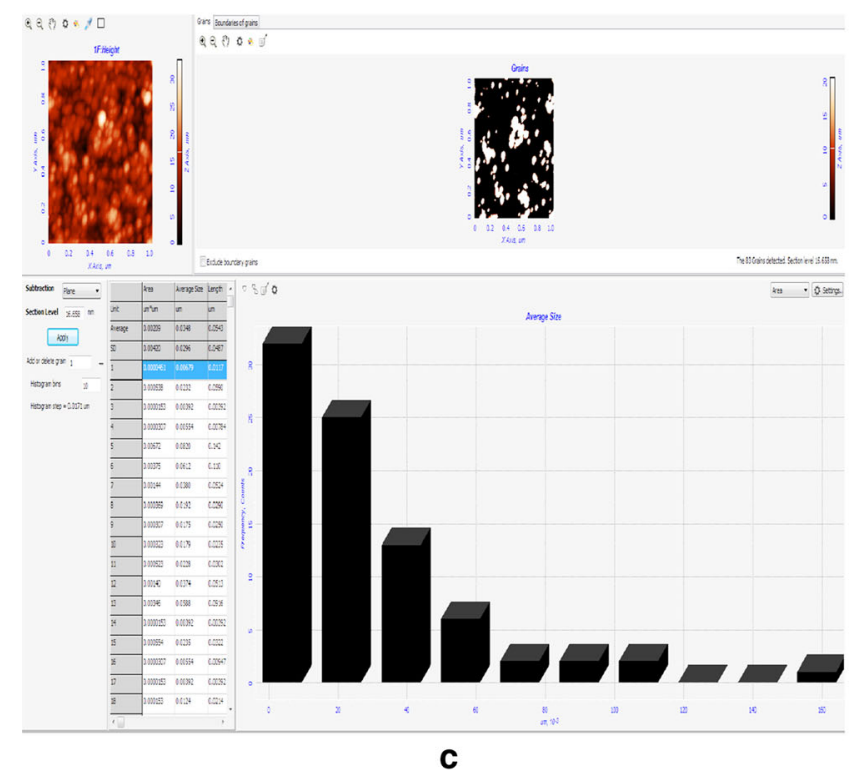

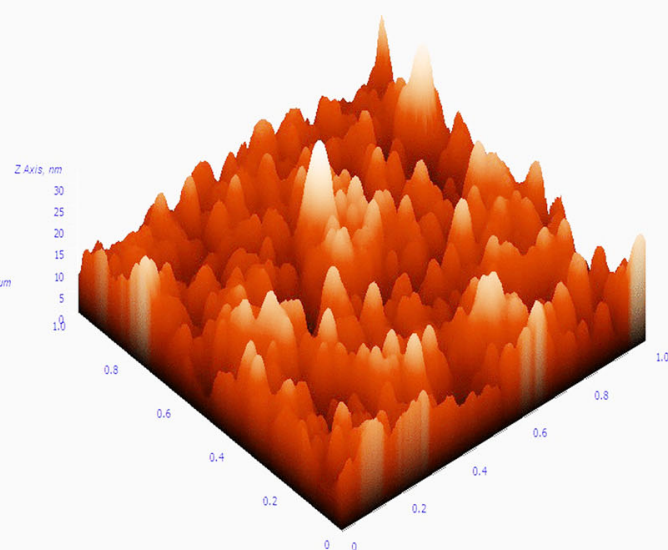

b

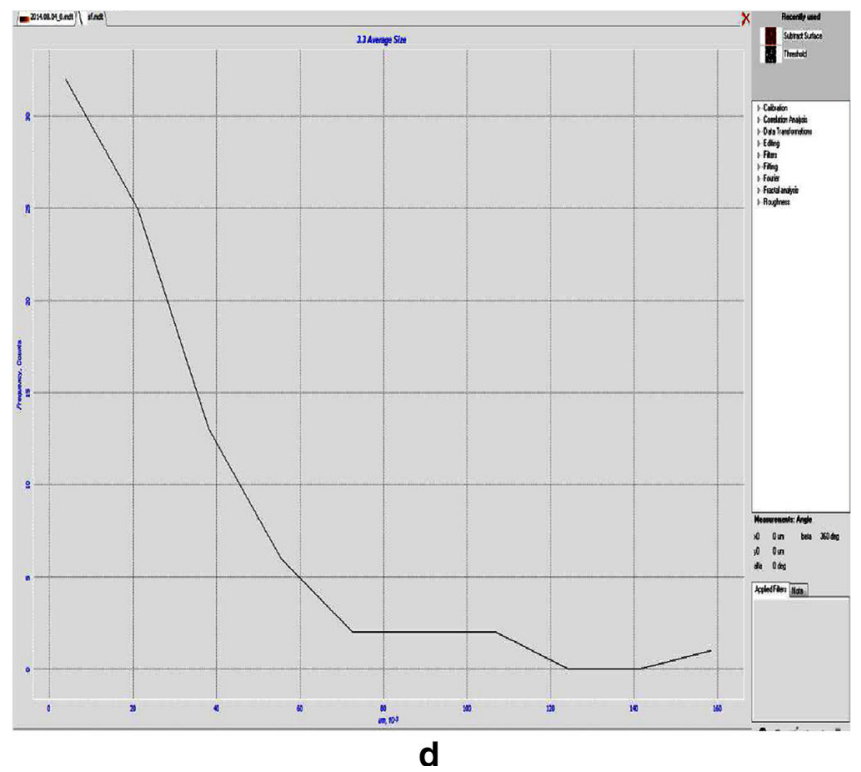

Fig. 5 a $2 \times 2 \mu \mathrm{m}$ Magnification studies of SNPs in AFM shows particles are spherical in shape and size from 32-68 nm, b 3D image, c and d average size of nanoparticles i.e., $34 \mathrm{~nm}$ analyzed by NOVA-TX software 


\section{SEM analysis}

Thin films of the sample were prepared on clean glass slide by just dropping $10 \mu \mathrm{l}$ of SNPs sample, extra solution was removed using a blotting paper and then the film was allowed to dry for $10 \mathrm{~min}$ in hot air oven. For conventional imaging in SEM analysis biological or insulating samples require thin conductive coating. The surface of the thin films coated with gold acts as electrically conductive agent. 300-nm (Fig. 6a) magnification analysis of SEM micrographs shows uniform distribution of SNPs on the surface, which are spherical in shape and size range from 21 to $25 \mathrm{~nm}$. Same type of results obtained from Acalypha indica leaf mediated synthesis of silver nanoparticles are spherical in shape and have size range between 20 to $30 \mathrm{~nm}$ ( $\mathrm{Kr}$ ishnaraj et al. 2010).

\section{EDAX analysis}

EDAX analysis was performed to know the percentage of $\mathrm{Ag}^{0}$ present in the sample. The EDAX spectra shows strong silver (12.74\%) absorption peak along with different elements with their weight percentage like Carbon (28.61\%), Nitrogen (02.21\%), Oxygen (09.04\%), Sodium $(04.30 \%)$, Magnesium $(01.40 \%)$, Aluminium $(00.56 \%)$, Silicon (23.46\%), Aurum (12.97\%) and Calcium $(04.72 \%)$ in the sample. (Figure $6 \mathrm{~b}, \mathrm{c})$. The results indicated that the reaction product has high purity of SNPs.

\section{TEM analysis}

Morphological structure and distribution of synthesized silver nanoparticles characterized at high magnifications $(20 \mathrm{~nm})$ were done by TEM. For TEM analysis the SNPs are coated on copper grids and analyzed by Hitachi HF3300 advanced with $300 \mathrm{kV}$. Selected area electron diffraction (SAED) pattern shows that the nanoparticles are crystalline in nature (Fig. 7a). 20-nm scale bar studies of TEM micrographs of SNPs signify that the synthesized nanoparticles are polydispersed, predominantly spherical in shape, owing 5-10 nm size and are not in physical contact with each other i.e., no agglomeration of nanoparticles were seen (Fig. 7b).

\section{Antimicrobial studies}

Biologically synthesized SNPs are analyzed to their toxicity on two Gram-positive and five Gram-negative bacterial strains growing on nutrient agar medium and five fungal strains growing on potato dextrose agar medium. The obtained zone of inhibition of different extracts was compared with two standard drugs viz., Streptomycin for bacteria and Fluconazole for fungi. Maximum inhibition zones of synthesized SNPs of bacteria were observed in $S$. typhimurium followed by $P$. vulgaris, $K$. pneumoniae, E. coli, P. aeruginosa, S. aureus and B. Subtilis (Fig. 8a; Graph 1; Table 1). Whereas in the case of fungi highest inhibition zones were observed in $A$. solani followed by $A$. niger, A. flavus, T. harzianum and $P$. chrysogenum (Fig. 8b; Graph 2; Table 2). Gram-negative bacteria are more susceptible when compared to the Gram-positive bacteria. The Gram-positive bacteria having thick layers of peptidoglycons (together with polypeptide contains proteins) when compared to the Gram-negative bacteria and the penetration of SNPs through cell membrane is easy in case of Gram-negative bacteria. The cell walls of fungi made up of chitin (a type of polysaccharide contains nitrogen) is having more complex structure than bacteria.
Fig. 6 a $300 \mathrm{~nm}$ magnification studies of SNPs in SEM shows nanoparticles are spherical in shape and size from 21 to $25 \mathrm{~nm}$ b and c EDAX analysis of Ag metal in sample shows by weight percentage

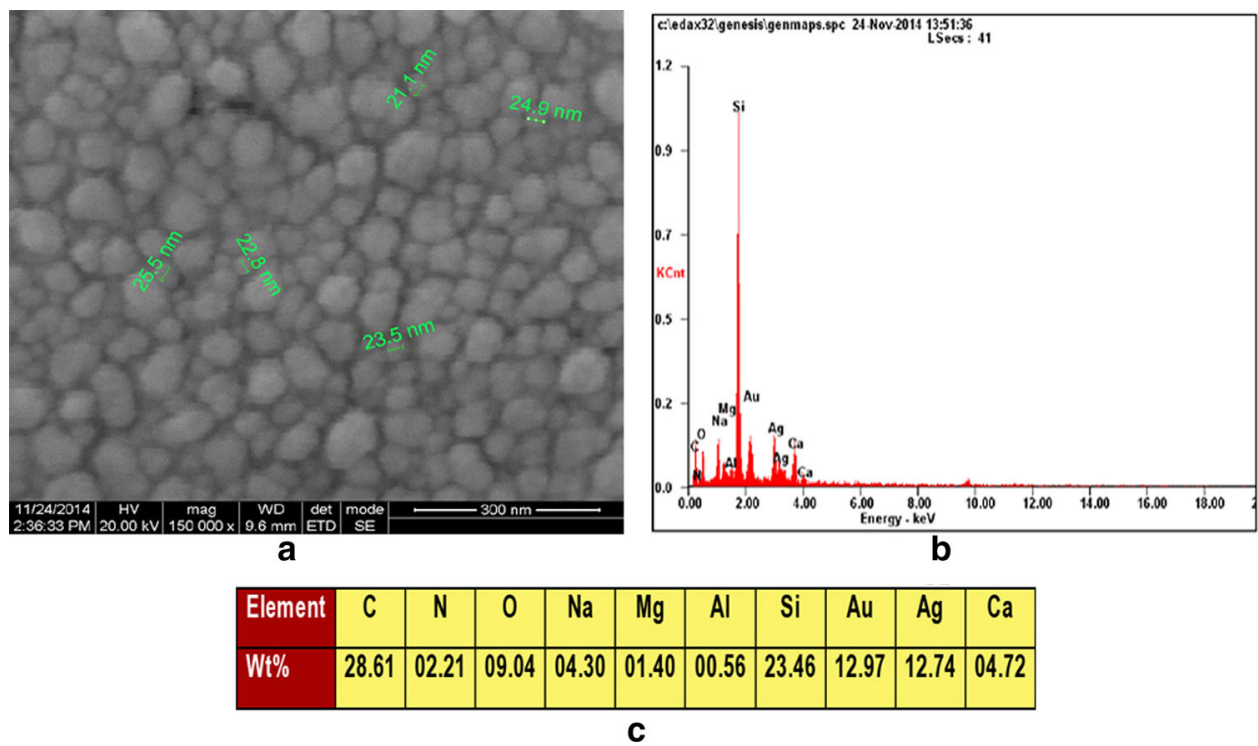


Fig. 7 a SAED studies of synthesized nanoparticles, b $20 \mathrm{~nm}$ magnification studies of SNPs shows nanoparticles are spherical in shape and size from $5-10 \mathrm{~nm}$
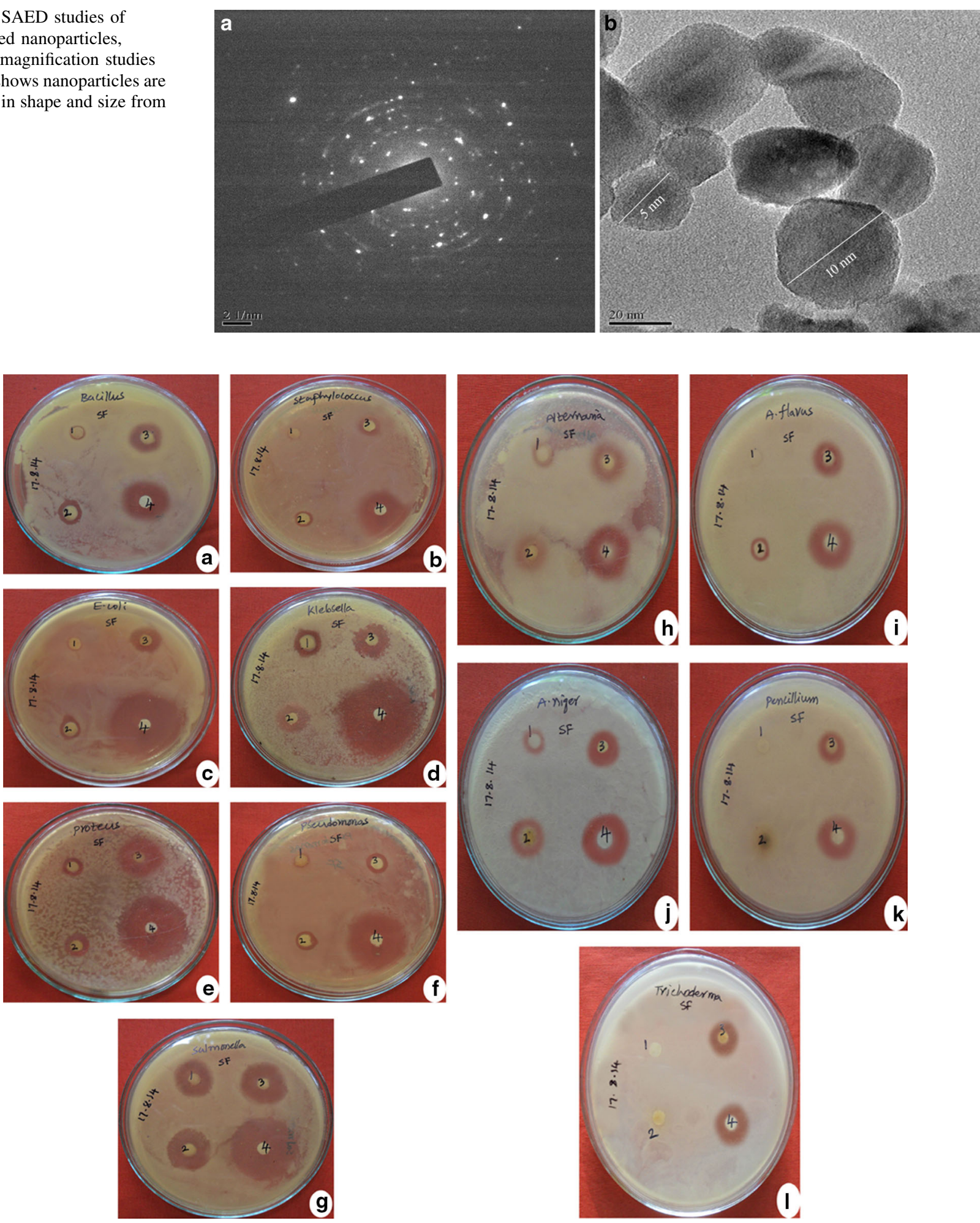

Fig. 8 a Antibacterial studies of synthesized SNPs, b antifungal studies of synthesized SNPs. a B. subtilis, b $S$. aureus, c E. coli, d $K$. pneumoniae, e $P$. vulgaris, $\mathbf{f} P$. aeruginosa, $\mathbf{g}$ S. typhimurium, $\mathbf{h}$. A. solani, $\mathbf{i}$ A. flavus, $\mathbf{j}$ A. niger, $\mathbf{k}$ P. chrysogenum and $\mathbf{l} T$. harzianum, 1 Plant extract, $2 \mathrm{Ag}\left(\mathrm{NO}_{3}\right)_{2}, 3$ SNPs, 4 Streptomycine/Fluconazole

From these observations, the results obtained here are bacterial strains that show high susceptibility to SNPs when compared to fungi. SNPs from Carica papaya fruit with
25-50 nm, spherical shaped nanoparticles are high toxic towards Escherichia coli and Pseudomonas aeruginosa (Devendra et al. 2009). Vitis venifera fruit mediated 
Graph 1 Graphical representation of zone of inhibition for bacterial species against synthesized SNPs from S. alternifolium

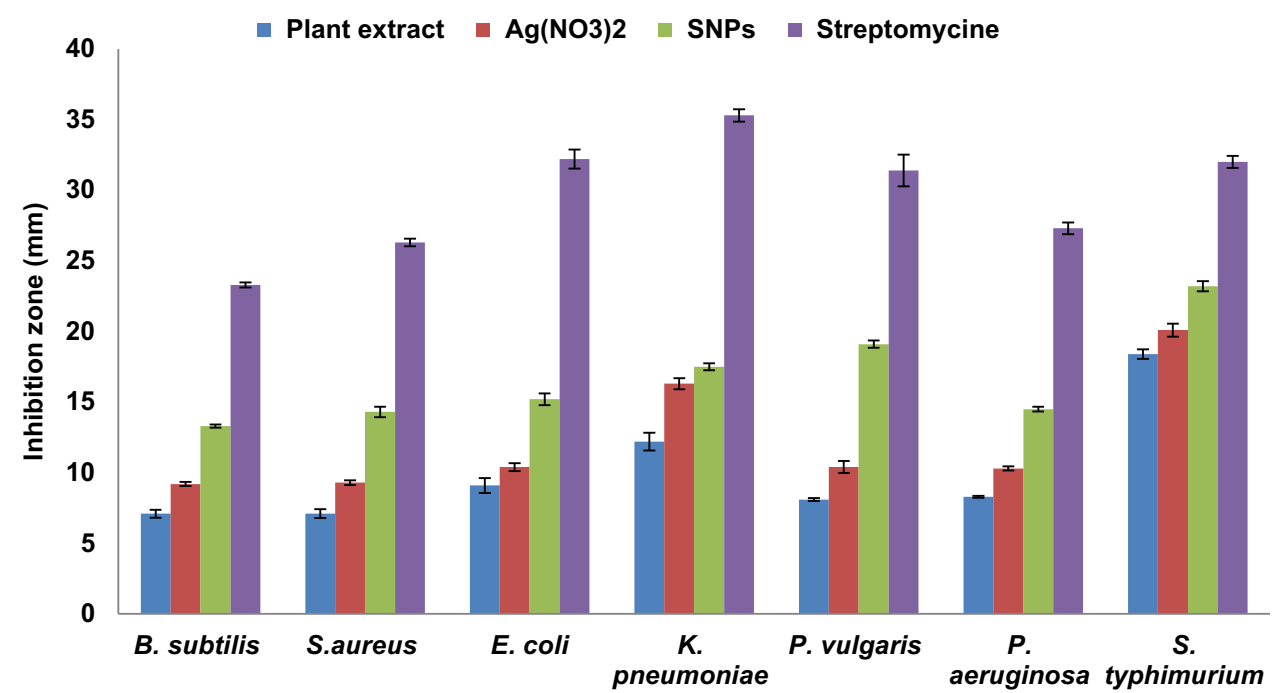

Table 1 Effect of synthesized SNPs on different species of bacteria

\begin{tabular}{|c|c|c|c|c|c|}
\hline \multirow[t]{2}{*}{ S. no } & \multirow[t]{2}{*}{ Name of the organism } & \multicolumn{4}{|c|}{ Inhibition zone (mm) } \\
\hline & & Plant extract & $\mathrm{Ag}\left(\mathrm{NO}_{3}\right)_{2}$ & SNPs & Streptomycin \\
\hline 1 & B. subtilis & $7.1 \pm 0.28$ & $9.2 \pm 0.14$ & $13.3 \pm 0.12$ & $23.3 \pm 0.18$ \\
\hline 2 & S. aureus & $7.1 \pm 0.32$ & $9.3 \pm 0.17$ & $14.3 \pm 0.36$ & $26.3 \pm 0.26$ \\
\hline 3 & E. coli & $9.1 \pm 0.53$ & $10.4 \pm 0.28$ & $15.2 \pm 0.42$ & $32.2 \pm 0.67$ \\
\hline 4 & $K$. pneumoniae & $12.2 \pm 0.63$ & $16.3 \pm 0.39$ & $17.5 \pm 0.25$ & $35.3 \pm 0.44$ \\
\hline 5 & P. vulgaris & $8.1 \pm 0.10$ & $10.4 \pm 0.43$ & $19.1 \pm 0.26$ & $31.4 \pm 1.13$ \\
\hline 6 & P. aeruginosa & $8.3 \pm 0.07$ & $10.3 \pm 0.14$ & $14.5 \pm 0.17$ & $27.3 \pm 0.41$ \\
\hline 7 & S. typhimurium & $18.4 \pm 0.34$ & $20.1 \pm 0.46$ & $23.2 \pm 0.36$ & $32.0 \pm 0.42$ \\
\hline
\end{tabular}

Values are average of triplicates, \pm indicates standard error

Graph 2 Graphical representation of zone of inhibition for fungal species against synthesized SNPs from $S$. alternifolium

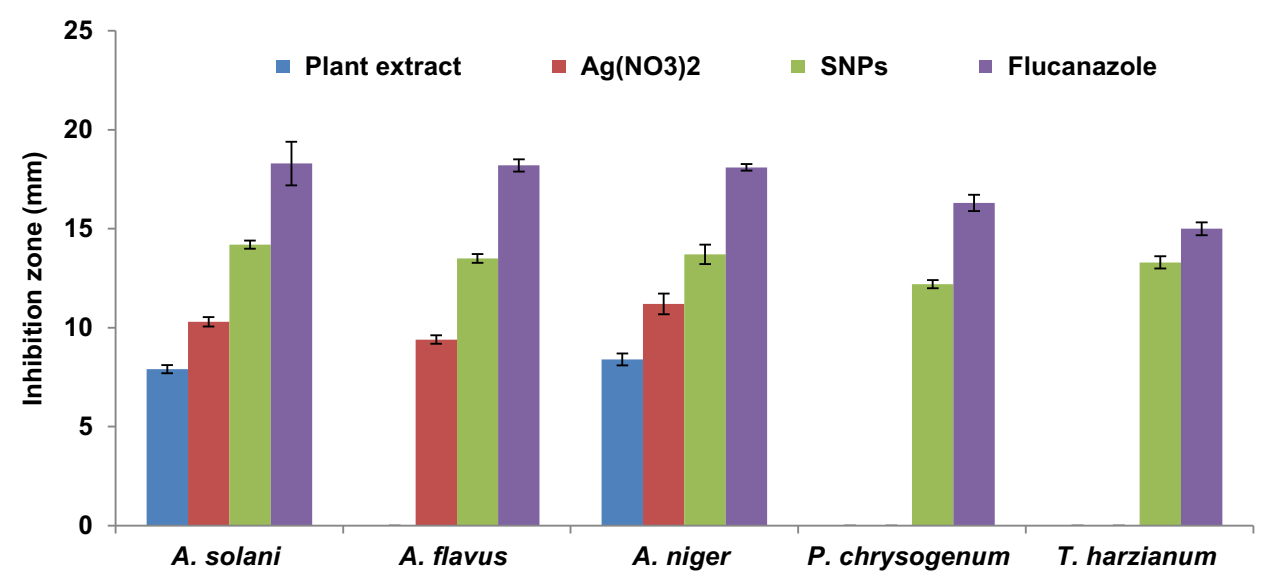

syntheses of SNPs are spherical in shape, size range between 30 and $40 \mathrm{~nm}$ having excellent antibacterial activity against Bacillus subtilis and Klebsiella planticola (Gnanajobitha et al. 2013). The exact mechanism of antimicrobial activity is not known but some of the scientists state that SNPs may attach to the surface of the cell membrane and disturb its permeability and cause structural changes on cell membrane of bacteria (Sondi and Sondi 2004) and destruct membrane integrity of fungal spores (Krishnaraj et al. 2012) leading to cell death. Some of the scientists state that the SNPs penetrate inside the bacteria and fungi causing damage by interacting with electron 
Table 2 Effect of synthesized SNPs on different species of fungi

\begin{tabular}{|c|c|c|c|c|c|}
\hline \multirow[t]{2}{*}{ S. no } & \multirow[t]{2}{*}{ Name of the organism } & \multicolumn{4}{|c|}{ Inhibition zone (mm) } \\
\hline & & Plant extract & $\mathrm{Ag}\left(\mathrm{NO}_{3}\right)_{2}$ & SNPs & Fluconazole \\
\hline 1 & A. solani & $7.9 \pm 0.21$ & $10.3 \pm 0.24$ & $14.2 \pm 0.21$ & $18.3 \pm 0.33$ \\
\hline 2 & A. flavus & 0 & $9.4 \pm 0.22$ & $13.5 \pm 0.22$ & $18.2 \pm 0.41$ \\
\hline 3 & A. niger & $8.4 \pm 0.30$ & $11.2 \pm 0.52$ & $13.7 \pm 0.49$ & $18.1 \pm 0.17$ \\
\hline 4 & P. chrysogenum & 0 & 0 & $12.2 \pm 0.21$ & $16.3 \pm 0.31$ \\
\hline 5 & T. harzianum & 0 & 0 & $13.3 \pm 0.31$ & $15.0 \pm 1.10$ \\
\hline
\end{tabular}

Values are average of triplicates, \pm indicates standard error

phosphorous and sulphur containing compounds such as DNA and proteins, resulting in cell death (Baker et al. 2005). In the present study, AFM, SEM and TEM studies of synthesized SNPs confirm that the nanoparticles are very small in size and owe spherical shape.

\section{Conclusion}

In the present study we have reported a simple, ecofriendly and low cost method for stable silver nanoparticles synthesized from fruit extract of $S$. alternifolium an important endemic medicinal plant as a reducing agent. The colour change pattern and surface plasmon resonance spectra of UV-VIS data $(442 \mathrm{~nm})$ confirms the formation of SNPs. Phenols and Proteins are mainly responsible for reduction and stabilization of these SNPs revealed by FTIR. Very fine and small-sized nanoparticles were recognized if the magnification of micrographs is increased i.e., $2 \mu \mathrm{m}$ in AFM, $300 \mathrm{~nm}$ in SEM and $20 \mathrm{~nm}$ in TEM. In TEM higher magnification and higher resolution is possible up to $20 \mathrm{~nm}$, whereas in the case of AFM and SEM the magnification is possible to above mentioned, but the resolution is not possible. $32-68 \mathrm{~nm}$ size of SNPs are recognized in AFM $(2 \times 2 \mu \mathrm{m}$ magnification), 21-25 nm of SNPs recognized in SEM (300 $\mathrm{nm}$ magnification) and 5-10 nm of SNPs recognized in TEM analysis (20 nm scale bar). Due to higher magnification and higher resolution in TEM analysis, the recognition of small particles is possible and it also an advanced tool to give better results instead of AFM and SEM. But all the microscopic studies reveal that the nanoparticles are well dispersed showing no agglomeration and mostly spherical in shape and size range from 5 to $68 \mathrm{~nm}$. The synthesized SNPs from $S$. alternifolium exhibit excellent antimicrobial activity against different clinically isolated bacteria and fungi. Therefore, these biologically synthesized SNPs are ecofriendly antimicrobial agents and high quantity production of nanoparticles with little volume of plant extract is high conservable significance in this medicinal endemic plant.

Acknowledgments The authors are highly thankful to UGC for providing BSR fellowship and highly grateful to DST-PURSE, Sri Venkateswara University-Tirupati, JNTU-Hyderabad and SAIF, IITMadras for technical support.

Open Access This article is distributed under the terms of the Creative Commons Attribution License which permits any use, distribution, and reproduction in any medium, provided the original author(s) and the source are credited.

\section{References}

Anamika M, Sanjukta C, Prashant MR, Geeta W (2012) Evidence based green synthesis of nanoparticles. Adv Mater Lett 3:519-525. doi:10.5185/amlett.2012.icnano.353

Ankanna S, Savithramma N (2011) Evaluation of secondary metabolites of Shorea tumbuggaia roxb. A globally threatened medicinal tree taxa of sheshachalam biosphere reserve. Int $\mathbf{J}$ Pharm Pharm Sci 3:403-405

Ankanna S, Prasad TNVKV, Elumalai EK, Savithramma N (2010) Production of biogenic silver nanoparticles using Boswellia ovalifoliolata stem bark. Dig J Nanomater Biostruct 5:369-372

Baker C, Pradhan A, Pakstis L, Pochan DJ, Shah SI (2005) Synthesis and antibacterial properties of silver nanoparticles. J Nanosci Nanotechnol 5:24-29

Bhumi G, Savithramma N (2014a) Biological synthesis of zinc oxide nanoparticles from Catharanthus roseus (L.) G. Don. Leaf extract and validation for antibacterial activity. Int J Drug Dev Res 6:208-214

Bhumi G, Savithramma N (2014b) Synthesis, characterization and evaluation of silver nanoparticles through leaves of Abrus precatorius L.: an important medicinal plant. Appl Nanosci. doi:10.1007/s13204-014-0295-4

Bhuvaneswari R, Chidambaranathan N, Jegatheesan K (2014) Hepatoprotective effect of Embilica officinalis and its silver nanoparticles against ccl4 induced hepatotoxicity in wistar albino rats. Dig J Nanomater Biostruct 9:223-235

Biodiversity news (2009) Endangered plants of Andhra Pradesh adivineredu Syzygium alternifolium. Biodivers News Andhra Pradesh 2:1-8

Cruickshank R (1986) Medical microbiology: a guide to diagnosis and control of infection. E\&S. Livingston Ltd., Edinburghand, p 888 
Devendra J, Daima HK, Sumita K, Kothari SL (2009) Synthesis of plant-mediated silver nanoparticles using papaya fruit extract and evaluation of their anti microbial activities. Dig J Nanomat Biostruct 4:723-727

Gamble JS (1915-1936). Flora of the Presidency of Madras. Authority of the Secretary of State for India in council, Dehra Dun, India, pp 5-1597

Gnanajobitha G, Paulkumar K, Vanaja M, Rajeshkumar S, Malarkodi C, Annadurai G, Kannan C (2013) Fruit-mediated synthesis of silver nanoparticles using Vitis vinifera and evaluation of their antimicrobial efficacy. J Nanostruct Chem 3:1-6

Gopinath K, Gowri S, Arumugam A (2013) Phytosynthesis of silver nanoparticles using Pterocarpus santalinus leaf extract and their antibacterial properties. J Nanostruct Chem 3:1-7. doi:10.1186/ 2193-8865-3-68

Herrera-Becerra R, Zorrilla C, Rius JL, Ascencio JA (2008) Electron microscopy characterization of biosynthesized iron oxide nanoparticles. Appl Phys A Mater Sci Process 9:241-246. doi:10.1007/s00339-008-4420-7

Javad KA, Sasan M (2013) Phytosynthesis of cadmium oxide nanoparticles from Achillea wilhelmsii flowers. J Chem 2013:1-4. doi:10.1155/2013/147613

Krishnaraj C, Jagan EG, Rajasekar S, Selvakumar P, Kalaichelvan PT, Mohan N (2010) Synthesis of silver nanoparticles using Acalypha indica leaf extracts and its antibacterial activity against water borne pathogens. Colloids Surf B 76:50-56. doi:10.1016/j. colsurfb.2009.10.008

Krishnaraj C, Ramachandran R, Mohan K, Kalaichelvan PT (2012) Optimization for rapid synthesis of silver nanoparticles and its effect on phytopathogenic fungi. Spectrochim Acta, Part A 93:95-99. doi:10.1016/j.saa.2012.03.002

Lee HJ, Song JY, Kim BS (2013) Biological synthesis of copper nanoparticles using Magnolia kobus leaf extract and their antibacterial activity. J Chem Technol Biotechnol 88:1971-1977. doi:10. $1002 /$ jctb. 4052

Maensiria S, Laokula P, Klinkaewnaronga J, Phokhaa S, Promarakc $\mathrm{V}$, Seraphin $\mathrm{S}$ (2008) Indium oxide $\left(\mathrm{In}_{2} \mathrm{O}_{3}\right)$ nanoparticles using Aloe vera plant extract: synthesis and optical properties. J Optoelectron Adv Mater 10:161-165

Mohan BA, Lakshmi BB (2000) Brief note on Syzygium alternifolium (Wight) Walp., an endemic plant species found in Sri Venkateswara Wildlife Sanctuary of Andhra Pradesh, with special reference to its fruiting. Zoos' Print J 15:210. doi:10. 11609/JoTT.ZPJ.15.2.210

Morones JR, Elechiguerra JL, Camacho A, Holt K, Kouri JB, Ramirez JT, Yacaman MJ (2005) The bactericidal effect of silver nanoparticles. Nanotechnology 16:2346-2353. doi:10.1088/ 0957-4484/16/10/059

Rafie HME, Hamed MAA (2014) Antioxidant and anti-inflammatory activities of silver nanoparticles biosynthesized from aqueous leaves extracts of four Terminalia species. Adv Nat Sci Nanosci Nanotechnol 5:1-11. doi:10.1088/2043-6262/5/3/035008

Rao BK (2004). Hypoglycaemic and antihyper glycemic effects of Syzygium alternifolium (seed) on Alloxon Diabetic rats. Dissertation, Sri Venkateswara University, Tirupati

Rao BK, Rao CH (2001) Hypoglycemic and antihyperglycemic activity of Syzygium alternifolium (Wt.) Walp. seed extracts in normal and diabetic rats. Phytomedicine 8:88-93

Reddy KN, Reddy CS (2008) First red list of medicinal plants of Andhra Pradesh, India-Conservation assessment and management planning. Ethnobot Leafl 12:103-107

Sankar NS, Dipak P (2014) Eco-friendly green synthesis and spectrophotometric characterization of silver nanoparticles synthesized using some common Indian spices. Int J Green Herb Chem 3:401-408
Sankar NS, Dipak P, Nilu H, Dipta S, Samir KP (2014) Green synthesis of silver nanoparticles using fresh water green alga Pithophora oedogonia (Mont.) Wittrock and evaluation of their antibacterial activity. Appl Nanosci 1-7. doi:10.1007/s13204014-0366-6

Sathyavathi R, Krishna MB, Rao SV, Saritha R, Rao DN (2010) Biosynthesis of silver nanoparticles using Coriandrum sativum leaf extract and their application in nonlinear optics. Adv Sci Lett 3:1-6. doi:10.1166/asl.2010.1099

Savithramma N, Venkateswarlu P, Suhrulatha D, Basha SKM, Devi CVR (2010) Studies of Boswellia ovalifoliolata Bal. and Henry-an endemic and endangered medicinal plant. Bioscan $5: 359-362$

Savithramma N, Rao ML, Devi PS (2011a) Evaluation of antibacterial efficacy of biologically synthesized silver nanoparticles using stem barks of Boswellia ovalifoliolata Bal. and Henry and Shorea tumbuggaia Roxb. J Biol Sci 11:39-45. doi:10.3923/jbs. 2011.39.45

Savithramma N, Rao ML, Basha SKM (2011b) Antifungal efficacy of silver nanoparticles synthesized from the medicinal plants. Der Pharma Chemica 3:364-372

Savithramma N, Yugandhar P, Rao ML (2014a) Ethnobotanical studies on Japali hanuman theertham-a sacred grove of Tirumala hills, Andhra pradesh, India. J Pharm Sci Res 6:83-88

Savithramma N, Yugandhar P, Babu RH, Prasad KS (2014b) Validation of indigenous knowledge of yanadi tribe and local villagers of Veyilingalakona-a sacred grove of Andhra Pradesh, India. J Pharm Sci Res 6:382-388

Seema G, Amrish C (2012) Bio synthesis and anthelmintic activity of silver nanoparticles using aqueous extract of Saraca indica leaves. Int J Ther Appl 7:9-12

Seema G, Amrish C, Avijit M, Rupa M (2014) Green synthesis of silver nanoparticles using Arnebia nobilis root extract and wound healing potential of its hydrogel. Asian J Pharm 8:95-101. doi:10.4103/0973-8398.134925

Sharma G, Sharma AR, Kurian M, Bhavesh R, Nam JS, Lee SS (2014) Green synthesis of silver nanoparticle using Myristica fragrans (nutmeg) seed extract and its biological activity. Dig J Nanomat Biostruct 9:325-332

Sondi I, Sondi BS (2004) Silver nanoparticles as antimicrobial agent: a case study on E. coli as a model for Gram-negative bacteria. J Colloid Interface Sci 275:177-182. doi:10.1016/j.jcis.2004.02. 012

Sundaravadivelan C, Nalini PM, Sivaprasanth P, Kishmu L (2013) Biosynthesized silver nanoparticles from Pedilanthus tithymaloides leaf extract with anti-developmental activity against larval instars of Aedes aegypti L. (Diptera; Culicidae). Parasitol Res 112:303-311. doi:10.1007/s00436-012-3138-9

Swamy MK, Sudipta KM, Jayanta K, Balasubramanya S (2014) The green synthesis, characterization, and evaluation of the biological activities of silver nanoparticles synthesized from Leptadenia reticulata leaf extract. Appl Nanosci. doi:10.1007/s13204-0140293-6

The Wealth of India (1976) Raw materials. In: Publication and Information Directorate (ed). Council of Scientific and Industrial Research, New Delhi, p 93

Vasanth K, Ilango K, Mohankumar R, Agrawal A, Dubey GP (2014) Anticancer activity of Moringa oleifera mediated silver nanoparticles on human cervical carcinoma cells by apoptosis induction. Colloids Surf B 1:354-359. doi:10.1016/j.colsurfb. 2014.02.052

Venkateswarlu P, Ankanna S, Prasad TNVKV, Elumalai EK, Nagajyothi PC, Savithramma N (2010) Green synthesis of silver nanoparticles using Shorea tumbuggaia stem bark. Int J Drug Dev Res 2:720-723 
Veronica A, Isaac H, Jose RPV, Miguel JY, Horacio T, Patricia S, Jorge LGT (2004) Size controlled gold nanoparticle formation by Avena sativa biomass: use of plants in nanobiotechnology. J Nanopart Res 6:377-382. doi:10.1007/s11051-004-0741-4

Yang X, Qingbiao L, Wang H, Huang J, Lin L, Wang W, Su Y, Opiyo JB, Hong L (2009) Green synthesis of palladium nanoparticles using broth of Cinnamomum camphora leaf. J Nanopart Res 12:1589-1598. doi:10.1007/s11051-009-9675-1
Yugandhar P, Savithramma N (2013) Green synthesis of calcium carbonate nanoparticles and their effects on seed germination and seedling growth of Vigna mungo (L.). Hepper. Int J Adv Res 1:89-103

Zeba B, Anusha J, Kamala K, Sam JKE (2012) Anti ulcer activity of Syzygium alternifolium against ethanol and NSAID induced ulcer in rats. Int J Res Pharmacol Pharmacother 1:18-22 